\title{
BILINGUALISM IN EDUCATION
}

A JOINT meeting of Sections L (Education) and $J$ (Psychology) of the British Association devoted to "Bilingualism in Education" was held in Dublin on September 9. Three papers were read, and they were followed by discussion.

The first was given by Sir Ben Bowen Thomas, Permanent Secretary of the Welsh Department of the Ministry of Education. His subject was "An Administrator's Approach to the Implementation of a Bilingual Education Policy". He defined a bilingual policy in education as one which is designed to enable the average pupil to attain a mastery of his mother tongue and a working competence in the second language current within his society, and if possible to achieve this by the time the pupil reaches his twelfth year, and in any event not later than the end of his period of compulsory education. That the Welsh language should still be standing up to English at all looked like a bit of unrealistic importunity, but this reflected the will to survive of "a strange, intelligent people".

An administrator does not lay down general policy ; he must understand it and, within the limits of statutory provision and financial resources, devise ways and means of giving it effect. Education policy in general is justified and sustained by reference to public opinion, both national and local. The policy of bilingualism in education is the result of three social forces, namely : a respect for tradition, the will to survive, and a sense of fair play. An admin. istrator will seek to implement it in a way that supports trends that favour it and gives no offence to forces that may be opposed to it. $\mathrm{He}_{e}$ has to devise a policy in consultation with local education authorities and have confidence in them to apply it in varying ways. He will not associate bilingualism with political controversy, but deal with it as an educational issue.

In England and Wales, the Ministry places direct responsibility for it on its Welsh Department. Successive Ministers have pronounced in its favour. The administrator implements it according to the provisions of the Education Acts. Three sections of the Education Act of 1944 concern it : the first asks the Minister to promote the education of the people and develop institutions devoted to that purpose. Pre-eminent among these in Wales is the Welsh language. Section 62 requires the Minister to see that enough teachers are forthcoming, including the right kinds. Section 76 provides, with cortain safeguards, that children shall be educated according to the wishes of their parents. The administration of these sections means that bilingualism in Welsh education has been increasingly clarified. More competent bilingual teachers have been employed, suitable educational equipment, including more and better books, has been provided, and the range of choice for parents is wider than it used to be, particularly after the increase in the number of Welshlanguage schools in urban areas.

Wolsh local education authorities have acted singly and collectively. Some have appointed language organizers, have stimulated the production of suitable text-books, and have formulated clear bilingual policies in terms of school organization.
Their collective instrument is the Welsh Joint Education Committee, which is working, with the University of Weles, to break the vicious circle of the lack of qualified graduates and teachers due to secondary schools not sending suitably equipped students to the university and the training college, which is due in turn to lack of qualified bilingual teachers in secondary schools. It is subsidizing competent research into bilingualism in education, because there is now great scope for parading prejudices and superficial impressions about bilingualism as authoritative views. This is a process which is exercising a bad influence on public opinion, making unnecessary difficulties for some local authorities at a critical stage of their efforts to apply sound educational policies. Compulsion is out of the question. The conclusion of the Central Advisory Council for Education (Wales) still holds : "We do not anticipate that a measure that would in any way upset the present delicately adjusted equilibrium of educational administration would react at ull favourably upon the place of the Welsh language in the schools". If this policy of bilingualism in education is to succeed, statesmen must be able to count on the support of public opinion and administrators, and teachers and parents must have confidence in one another.

The second paper was given by Mr. J. R. Morrison, a Gaelic-speaking Scotsman, who is now on the staff of the Education Department in the University College of Wales, Aberystwyth. $\mathrm{He}$ gave some interesting summaries of psychological research work that had been undertaken in Wales, Scotland and Canada, concluding that not enough has been done under satisfactory conditions to justify firm conclusions of any kind.

The results of the Welsh experiments seemed to establish that reactions to emotionally charged words vary according to the language in which the bilingual child hears them: for example, 'nasty', 'wicked', 'sister', when spoken in Welsh to a bilingual child, produced quicker reactions than the English words, whereas 'lazy' had a greater emotional impact in English for the same children, perhaps because English was the dominating language in the school investigated. Girls seem to be more favourably disposed to bilingualism than boys, and children of Welsh-speaking mothers more so than those of Welsh-speaking fathers. Bilingual children usually scored less in tests of intelligence and of English attainment, but in non-verbal intelligence tests they were nearly or quite equal to monoglots, especially if the test used had no time limit. It was only a minority of children that was definitely equally at home in both languages.

Mr. Morrison described in some detail the results of an investigation by a Canadian neurologist. He seemed to have established that the speech areas of the brain begin to lose their sensitivity after a child reaches the age of ten years, and that they are senescent by the age of fourteon. If this is so, the period of primary education is of vital significance for bilingualism. Mr. Morrison concluded that controlled experimentation on a much wider scale than anything that has yet been attempted is neces- 
sary before the complexities of the problem can be unravelled and reliable educational guidance given to teachers.

The third paper was given by Prof. E. F. O'Doherty, professor of logic and psychology in University College, Dublin. He dealt with some educational aspects of bilingualism.

In his view, the emotional life of a large number of children is disturbed by the pseudo-bilingualism in which Irish children find themselves in their early years, because they came from English-speaking homes but received their instruction, from thoir earliest year's, through the Irish language. $\mathrm{He}$ maintained that the language of the home, whatever it is, is the child's native language, and that it is a mistake to confuse this with the ancestral language of the people to whom he belongs. In nearly all countries there is a bilingual problem, and in nearly all the hundred or more studies available on the topic, investigators have consistently recommended that children should be taught their native, that is, home, language and in other subjects through that medium. Language, a system of symbols, can become a symbol of a different kind -it can become a symbol of nationality or of culture, or of lack of culture ; as a symbol of political independence or of nationality it can be valuable, but as a symbol it is dangerous because it may take precedence over the thing that it symbolizes. The primary purpose of language is a social one, and the first society in which it is acquired is the home. The language of the home is always the child's native language, and his mother tongue. To confuse the native language with the conception of an ancestral language may inflict great harm, because it means the by-passing of the child's normal means of social intercourse in favour of what for many, though not all, is the ancestral language. This has many undesirable effects.

It is also important, Prof. O'Doherty said, to distinguish betwoen bilingualism and pseudo-bilingualism. 'The latter is the position of $\omega$ person who has achieved a mastery, proportioned to his age and social group, over one means of social intercourse and who has also acquired some knowledge of another means of communication without mastering it. A bilingual person is one who has two vernaculars. This is a rare phenomenon indeed compared with the number of pseudo-bilinguals in any population. Although research is incomplete, there is no denying the impressiveness of the conclusions that monoglot children do better in intelligence tests than their bilingual and pseudo-bilingual brothers. Very often the problem of bilingualism is decided on grounds other than the intelligence or the welfare of the children-politics, tradition, culture, have provided powerful incentives. Where that has happened, bad psychology, bad educational philosophy and bad educational practice have crept in. The emotional life of a large number of children is disturbed by the pseudo-bilingual situation. Unconscious disturbances precipitated by the total or partial breakdown in communication due to the language barrier can produce long-range effects of some magnitude. In Ireland their contribution to the problem of emigration should not be under-estimated.

In the discussion which followed, speakers included teachers from the universities, training colleges and primary schools. On the whole, they expressed fixed attitudes to the subject, and did not bring to the discussion an open-minded willingness to elucidate the subject in its numerous facets. It was therefore inconclusive and rather disappointing. Charge was met by counter-charge, one body of experience was pitted against another, and the points made came entirely from the Irish situation, in which the great majority of the members of the joint session were involved.

\section{RESEARCH ON GELATIN AND GLUE}

$T$

HE conference on "Recent Advances in Gelatin and Glue Research", organized by the British Gelatine and Glue Research Association, and held in Cambridge during July 1-5, attracted 150 participants. The discussion which ensued after each group of papers was evidence of the success of the conference. Discussions were stimulated in part by the excellent standard of the papers and by the fact that the aim was to discuss but a single protein, albeit one of tremendous physiological and industrial importance. It is hoped to publish the proceedings before the end of this year, edited by G. Stainsby (Pergamon Press, Ltd.).

At the opening ceremony, Mr. S. G. Hudson, chairman of the Research Association, included in his preface to the Conference an especial welcome to the overseas visitors. The Conference was formally opened by Prof. F. J. W. Roughton, one of the visitors to the Association appointed by the Department of Scientific and Industrial Research. $\mathrm{He}$ then introduced Prof. L. Pauling, who gave the Conference Lecture, "Polypeptide Chains in Proteins". In proposing a vote of thanks to Prof. Pauling, Mr. I. H. Chayen (British Glues and Chemicals, Ltd.) stressed the interdependence of technology and fundamental science, and emphasized the especial need of the gelatine and glue industry for fundamental research in the protein field.

Prof. Pauling outlined the development of the modern concept of the helical structure of collagen from the earlier classical experiments of Astbury, Bernal and Fankuchen. Although, by admission, Prof. Pauling discussed few new results beyond the idea that hydrogen bonding at the backbone might be at $180^{\circ}$ rather than $120^{\circ}$, the lecture set the tone of the meetings. At all the later sessions the helical concept was mueh in evidence. Sessions were devoted to various subjects, each session being introduced by a speaker who outlined its scope and background, as follows : (1) structure, properties, origin of animal connective tissue (introduced by Prof. K. W. Gustavson, Swedish Tanners Research Association); (2) soluble collagens and molecular weight, shape and structure of gelatins (Dr. J. Pouradier, Kodak-Pathé, Paris); (3) synthetic polypeptides containing proline (Dr. C. H. Bamford, Courtaulds, Maidenhead); (4) conversion of collagen to gelatin and chemical composition (Mr. A. G. Ward, British Gelatine and Glue Research Association); (5) chemical and physical properties of gelatin and glue (Prof. J. D. Ferry, University of Wisconsin); (6) relation of properties to uses (Mr. J. N. Blake, Richard Hodgson and Sons, Ltd., Beverley).

Discussion on the structure of collagen was concerned with the relative merits of the two structures 